\title{
British Commercial Policy in the West Indies, $1783-93$
}

TN March 1775 Burke, speaking on conciliation with America, pointed out that the three branches of trade carried on by Great Britain with the continental colonies, with the West Indies, and with Africa respectively were 'so interwoven that the attempt to separate them would tear to pieces the contexture of the whole and, if not entirely destroy, would much depreciate the value of all the parts'. Eight years later thirteen of the continental colonies were placed, by the acknowledgement of American independence, outside the compact commercial system enclosed and guarded by the navigation acts. Now, it has of late been fully understood that the principles of British commercial policy were not altered by the events of the American Revolution. How then did the British government contrive to preserve its old monopolist system, and yet to avoid the injuries to the West.Indian trade which Burke had anticipated ?

In order to understand the points at issue, we must bear in mind certain of the conditions under which intercolonial trade in America was carried on previously to the revolutionary war. In particular we must remember that the thirteen colonies and the West Indies were not alone interested in the trade. Canada, Nova Scotia, and Newfoundland gladly exchanged fish and their scanty surplus stock of lumber and flour for the produce of the islands, although their geographical position placed them at a serious disadvantage as compared with their sister colonies to the South. ${ }^{1}$ British shipowners engrossed what they could of the carrying trade between the continent and the West Indies, but found themselves heavily handicapped by the advantages which the Americans enjoyed through otheir proximity to the islands, the low cost of their ships, and the ability of these tiny

\footnotetext{
1 It is diffioult to the the volume of this trade, aince most of it was conducted indirectly through the New England merchants. See the evidence of InspectorGeneral Irving before the Committeo of Trade, 30 March 1784 : Public Record Office, Bosird of Trade, Minutes of the Committee of Trade, 3, fo. 124. In 1772 out of 1208 vessels arriving in the West Indies from North Ameria only 13 were from these colonies : ibid. fo. 11.
} 
vessels to enter any and all ports. ${ }^{2}$ British and Irish fishermen competed in the sugar islands against New England rivals ; ${ }^{3}$ while Irish farmers, although denied the privilege of direct trade with the colonies until 1778 , easily ontdistanced the farmers of Virginia, North Carolina, and Pennsylvania in supplying beef and pork to West Indian markets." In the British Islands, then, were many persons who would gain from the interruption of the chief branch of intercolonial trade. But the West Indians were well supplied with friends in England who were prepared to support their interests. Great Britain had sixty million pounds invested in the islands $;^{5}$ three-quarters of a million of its revenue was derived from West Indian produce $;{ }^{\circ}$ British goods representing a much larger sum and slaves to the value of another half-million were disposed of by West Indian merchants ; ${ }^{7}$ and;

- Colonial-built vessels were generally inferior to Britieb-built, but were much oheaper : before the Committeo of Trade (Board of Trade, Min of Comm. of Trade, 7, fo. 486). They constituted three-quartors of all the veseals ongaged in trade between the North American continent and the islands: Brit. Mus, Add. M8. 12404. The Britich merehants who entered the trade sent out large shipe whioh usually followed a " threecornered' route from Grest Britain to North America, thence to the sugar islande, and thence again to Great Britain. But thesesels oould make only one voyage a yeer, could trade only at large Ameriann porte where their oargoes were collected, were relatively expensive to work, and were apt to be too late in reaching the islands : Correepondence of John Reynell among the uncatalogued family papers of Joeeph H. Costea, Eeq., of Philadelphis, Penneylvania. The Ameriaan merohanta carried on the balk of their trade in little cosoting vecsels of 40 to 60 tons, which skirted the whores of the continent and cruised at will through the islands, loading and disoharging cargo wherever advantage offered, and making two or three trips a year: Pemberton and Clifford papers in the library of the Pennsylvanis Historical Society, Philadelphia. Statistion will be found in the Minutes of the Committeo of Trade, Maroh to May 1784, Board of Trade, Min. of Comm. of Trade, 3.

- Add. M8. 12404, fo. 54 .

- Evidence presented by Irving before the Committee of Trade, 30 Maroh 1784 : Board of Trade, Min. of Comm. of Trade, 3, fo. 124. Irish meat, though eomewhat more expensive, was superior in quality and could be kept longer. Direct trade was legalized by $18 \mathrm{Goo}$. III, c. 65, and $20 \mathrm{Geo}$. III, c. 10. A certsin amount appears, however, to have been carried on previously to the pasage of these acts : Massachuretts Hidorical Saciety Colloctions, Seventh Beries, ix. 209, 304, 308, 307.

- Add. MS. 12413, fo. 20. State of the West Indies laid before parliament, March 1776. In the petition of the West India planters of February 1775 the amonnt is given as thirty millions (Parliamentary History, xviii. 219), but it may easily be demonitrated that the larger sum is approximately acourste. See Journale of the Anembly of Jamaica, viii 525.

- Speech of Glover in the houre of commons, March 1775 : Parh Hist. Iviii. 461. This estimete is epparently moderate. The duty on 16,000,000 owt. of engar (Public Reoord Office, Treasury Revenue Acoonnte, Misc. Engl, 65) at 6s. 3ith a hundredweight would amount to more than $\mathfrak{E} 500,000$. The duties and excise on $2,250,000$ gallons of rom (Tressury Revenue Accounts, Miso. Engl a5) at 5s. 018d. a gallon would mount to $£ 660,000$. Again, oustoms duties alone on all West Indis goode imported into Great Britain amounted to about $\$ 700,000$.

- Great Britain exported to the West Indie goods to the value of about $£ 1,200,000$. Of theec about one-quarter ware 'foreign' goods: Treas. Rev. Aco., Miso. Engl., 81; Add. M8. 12413, fo. 28 ; and Publ Roo. Off., Treas., 38. 69. 
finally, West Indien proprietors were scattered through most of the counties of England. ${ }^{8}$

But, before reviewing the deliberations on the subject, we must inquire whether any changes in the situation were produced by the war. As an immediate result of the outbreak of hostilities, trade relations between the British West Indies and the colonies in revolt became doubly prohibited-on the American side through the agreements against importation and exportation; and on the British by the prohibitory acts. The West Indians, drawing little comfort from the regrets expressed in their behalf by Congress ${ }^{\circ}$ and by Lord North, ${ }^{10}$ protested that existence under such conditions was impossible. ${ }^{11}$ In view of later events it is interesting to note how they actually fared. From the outset extraordinary expedientis were adopted for the securing of supplies. Prizes were offered in the islands for the raising of additionsl amounts of food-stuffs and for the taking of turtle and fish, ${ }^{18}$ and the planters were thus persuaded to withdraw a portion of their land and negroes from the ordinary processes of cultivation. At the same time the shipments of food from Ireland were largely increased, ${ }^{13}$ the freer exportation of grain from Great Britain to the West Indies was sanctioned by statute, ${ }^{14}$ lumber was brought from the Baltic, ${ }^{15}$ and both- lumber and provisions were secured to the largest possible extent from Canada, Florida, neighbouring islands belonging to neutral powers, and such parts of the thirteen colonies as were under British control. ${ }^{16}$ It must also be noted that the cargoes of the

- Lord Shelburne declared in November 1778 that 'there was scarcely ten miles together throughout the country where the house and estate of a rioh West Indian were not to be aen': Parl. Hirt. xix 1315. Persons rexident in England powed property to the value of $£ 14,000,000$ in the islands: Add. MS. 12413, fo. 20 .

- Congreses, highly pleased at the intervention of Jemaice in behalf of the northern colonies, addressed to the assembly of that inland on $25 \mathrm{July} 1775$ a letter of apologg: 'We knew that we must sacrifice our own [interest] and (which gave us equal uneasiness) thet of our friends who had never offended us, and who were conneoted with us by s sympathy of feelings under oppressions similar to our own': Ford, Journals of Congress, i. $79,80,194,204$.

10 Parl. Hist. xviii. 1058.

$u$ e.g. the addrese of the asembly of Barbedoes, Pabl Rec. Off., Colonial Office, 28. 58. See aleo the resolutions passed on 7 Februery 1776 by the society of West Indian merchants and planters in London. The minutes of the meetings held by the society and its committee, 1769-83, are precerved at the offloes of the prosent West India Committee in Seething Lane, London.

12 A peper on the Weet Indis Trade, Publ Roc. Off., Colonial Offico; 325. 6 ; Laws of Jamaica, 16 Geo. III, a. 12, and 16 Geo. III, c. 16; Journals of the Asembly of Jamaica, vi. 676, 679, 689.

- Correspondence relating to the trade of the United States with the British colonies, Colonial Office, 325. 6; Naval Office lists for Jamaica, 1781, Board of Trade, 6. 176.

16 13 Geo. III, a. 43, and 14 Geo. III, c. 5.

11 Paper on the West India trade, Colonial Office, 325. 6 ; Minutes of the West Indis Merchante for 11 May 1776.

14 Naval Offoe lists for Jamsica, 1781, Board of Trade, 6. 176 ; adverticement in 
many American vessels taken by British men-of-war or privateers during the earlier years of the struggle were purchased for consumption in the islands, ${ }^{1}$ ? and that some of the West Indians unquestionably found means to defy the prohibitory acts and carry on trade with their rebel friends. ${ }^{18}$ The exact measure of success which attended these efforts is not easily estimated on account of the various misfortunes which fell upon the islands at this time. Several suffered capture, followed by the temporary ruin or emigration of many of the substantial planting class ; and all were more or less devastated by a series of violent hurricanes which occurred, most unfortunately, during the later years of the war. In order to form a proper estimate it will be well to confine our attention to Jamaica, which escaped capture, and was, from its relatively great size, best able to sustain the effects of the storms. There, we find, supplies were irregular and often insufficient, ${ }^{19}$ and the productive power of the island was substantially reduced..$^{30}$ Hence the planters were in 1783 particularly sensitive to the evils which might ensue should their old trade with the continental colonies be restricted or cut off. Yet the war had in other respects greatly strengthened the arguments which might be advanced for restricting, if not prohibiting, trade between the islands and the United States. The loyalty of the remaining continental colonies was felt to have merited some reward, and the migration to them of the American loyalists increased both their claims to consideration and their ability to engage in the West Indian trade. Again, the shipowners could argue that rebels and aliens should not be allowed to engross an important branch of the British shipping industry, especially at a time when hundreds of vessels and thousands of seamen were rendered idle by the return of peace. ${ }^{\text {.1 }}$

Jamaica Mercury for 6 Ootober 1779 ; Correspondenos of Governor Dalling of Jamelas with governors and commanders in North America, Colonial Offios, 6. 80.

17 Pabl. Reo. Off., Admiralty, 1. 240 ; Minutes of tho West Indis Merchants for 5 December 1777, Boerd of Trade, Min. of Comm. of Trade, fo. 330.

1. Publ. Roc. Off., Admiralty, 1. 241. Liste and descriptions of the vessels seived by Admiral Parker's squadron. The trade arried on through St. Eustatius is wal known.

1) Treas., 64. 72. Lists of imports in British bottoms at Kingston, Jamaios, during the war. The years of greatest cosarity were 1776-8. But the ruinous prioes of food and lamber would indioate that the island was insuffioiently aupplied at other timee. Soo Jowmale of the Asembly of Jamaica, vii. 313, 314, 467, 577, for prioes in 1780, 1782, and 1783 ; also the Annwal Regivter for 1778, p. 304.

20 Treas., 38. 269. Imports into England from the West Indies, 1774-83. The importation of sugar declined gradually from 1776 to 1781 by 60 per oent. Camden, epesking on 30 May 1777 on Chatham's motion for putting an end to hostilities in Amarica, declared that two hundred families living in England on the revenues from their West Indian estates had already been obliged by loases to return to the islands : Park. Hist. rix. 339.

1 The number of seamen without employment after 1783 was estimated at the remarkable figure of 60,000 : Evidenoe of Irving, the former Inspector-General of 
When therefore in 1782 the British government faced the problem of settling the future commercial relations of the various parts of the Empire with the United States, it was confronted with decided differences of opinion in political and commercial circles as to the regulation of the West Indian trade. While these differences originated chiefly from the conflict of interests just noted, they were strongly accentuated for several months by the intense personal feeling to which the war had given rise. Thus the planters, in asking for absolute freedom of intercourse, gained support from many of those who sympathized most warmly with the American cause; while the shipowners, in demanding the exclusion of the Americans from the carrying trade, and the advocates of the loyal colonies, in urging that American produce should be barred from entering the islands, had on their side men who would not unwillingly have hindered the commercial development of the United States. There was even difference of opinion as to the method of procedure which the government should pursue. The majority of those interested advocated the conclusion of a commercial treaty in connexion with the treaty of peace, but others advised that the government should prescribe regulations by statute, and leave the Americans free to follow a similar course. Both methods were, in fact, tried by the three ministries which successively took the matter in charge.

The attempts of the first of these, the Shelburne administration, to arrive at a settlement need not detain us long. In the matter of negotiation nothing was done beyond the rejection of Franklin's proposal, made in July 1782, that each nation should, in matters of commerce, treat the subjects of the other exactly as it did its own. ${ }^{2}$. Nor was the ministry able to accomplish more through parliament. It will be remembered that Lord Shelburne, whose position had been far from strong at the opening of the session on 5 December 1782, was forced to resign on 24 February following, and that the unwillingness of George III to accept the coalition of Fox and Lord North occasioned a sort of interregnum in the government which lasted until 2 April. The time was evidently unsuitable for passing important legislation, but

Importe and Exports in Amerias before the Committeo of Trade, 1 April 1784, Boand of Trade, Min. of Comm. of Trade, 3, fo. 156 .

n Pabl Roo. Off., Foreign Office, Misc. 563. Franklin's proposel as originally stated bore no direot referenoe to the British colonies: Osprald to Shelburne, $10 \mathrm{July}$ 1782. But in the provicional treaty of peace agreed to by Oswald two months later Artiole IV stated that in all parts of the world the shipe and merchants of the two netions should, in the ports belonging to both, "enjoy the same protection and com. mercial privileges and be lisble only to the eame chargee and duties'. A draft of these artioles was enclosed by Oswald to Townehend in a dispatch of 7 Ootober 1782. They were rejeoted by the cabinet, and Strachey was ont to Paris to obtain their revision. Among other concessions he, seoured the elimination of any mention of commerce in the treaty. Soe Smyth, Franklin, vili. 628.

VOL. XXXI. - NO. OXXIII. 
the ministry was subjected to constant attack for its delay in providing for the resumption of trade with the United States, and before the coalition ministry was formed, Pitt, as chancellor of the exchequer, attempted to deal with the matter through a bill introduced just after Shelburne's fall. This bill granted practically all that Franklin had asked in the preceding autumn without stipulating for any return: ${ }^{24}$ its effect would have been to give the Americans not only the privilege of unrestricted trade in their produce and manufactures with the West Indies, but also that of sharing the carrying trade between the mother country and the islands. But for so hasty and complete a departure from the old commercial system the country was not prepared.

The bill was violently attacked by societies of merchants and chambers of commerce from the larger trading centres ${ }^{25}$ as well as in parliament. In the commons Burke, Fox, Lord Sheffield, and Sir Grey Cooper joined in opposing it ; but the leading part was played by that urbane and astute politician, William Eden, who, as a former lord of the committeo for trade, ${ }^{20}$ spoke with authority on commercial matters, and who, moreover, was at this time strengthening his long-standing connexion with North ${ }^{27}$ by working assiduously for the establishment of the coalition government. ${ }^{28}$ Brushing aside alike the generous principles of Pitt's bill and Burke's pleas for 'measures of unsolicited liberality', he declared that the amount of the concessions to be allowed to the Americans should be determined on the basis of strict bargaining. In order that the ministers might have time and authority to conclude the most favourable arrangement, he suggested that they should be given power to regulate the American trade for a limited period by orders in council. ${ }^{29}$ This

- For attacks in the press 800 for instance the Morning Chronicle for 10 Febratry 1783. Demands for action were also being heard in the house of commons, as in Burke's spooh of 28 Jannary reportod in the Morning Herald and Daily Advertioer for 29 January 1783 .

"The tert is given in Edwards, History of the West Indies (London, 1801), ii. 491. The bill was introduced on 3 Maroh.

"The West Indian merchanta and plenters in London took the lead in protesting against the bill and secured the co-operation of the ohamber of commerce at Glagow : Minutes of the West India Merchants for 6 and 21 Maroh 1783.

" Knox Papers, Hist. MSSS. Comm, Reports on Various Collections, vi. 265. Knox in 1779 wrote a highly interesting sketch of Eden's life and charater. While malicious and not entirely trustworthy, it throws much light on Eden's political career. Unless Knox was a consummate hypoorite, a reconciliation between the two men must have taken placo before 1781.

7 Eden was one of the commissioners tont to America in 1778. His connexion with North began several years before this (Hir. MSS. Comm, Stopford-Sackvitle MSB., ii. 10), and was considered extremely olose at this time (Hist. MSS. Comm, 10th Rep., Append, pt. vi, 54, Jenkinson to Robinson, 16 September 1782).

"s Eden's two patrons, Loughborough (Wedderburn) and Carlisle, it may be noted, bocame members of the coalition cabinet.

- Eden made this proposal as early as 7 March : London Chronide, 8 Maroh 1783. 
scheme, designed for the benefit of the incoming administration, found considerable support, and Pitt, failing to get oven the principle of his measure approved, finally proposed that consideration of the whole matter should be deferred until the first week in April. ${ }^{30}$ Before the discussion was resumed the government was in the hands of Fox and North.

Fox, as secretary for the foreign department, first took the matter in charge. Convinced that it was too important for hasty settlement by means of legislation, ${ }^{\text {11 }}$ he adopted Eden's plan of procedure by dropping Pitt's bill, ${ }^{32}$ and passed an enabling act to give authority to the Crown to regulate all trade with America by order in council for gix months. ${ }^{23}$ Meanwhile he reopened negotiations with the American commissioners at Paris. But if his method was the method of Eden, his views, as defined in his instructions to Hartley, his envoy at Paris, were not far removed from those of Pitt. He was quite willing that the Americans should trade freely in their own ships with the West Indies, provided that they carried raw produce only. ${ }^{\text {st }}$ That they should trade between the islands and the mother country the government, he said, could not permit until a full investigation had been held, since English 'prejudices' on the matter were so strong. ${ }^{35}$ Hartley received dispatches to this effect under the date of 10 June. He heard nothing further until he was informed, not from home, but by the American commissioners, of the issue on 2 July of an order in council for the regulation of the West Indian trade. ${ }^{*}$ Since this order embodied the policy actually maintained during the ten years following, and since its provisions seem to indicate that the government's views had suddenly and entirely changed on one of the two essential points at issue, it deserves to be examined with some care. Its terms are well known. The West Indians were allowed to import American lumber, flour, bread, grain, vegetables, and live stock, and to

- The debates continued from 5. March to 2 April. Pitt in his defenco showed none of his ueual self-confidence, admitting at the outset that he was "by no mosns tenacious of any part of the bill', and laying himself open to ohargee by Sheffleld of weakness and vacillation. Reports of his prinoipal apeoches aro found in tho Morning Chronicle for 6 and 8 Maroh and 3 April 1783.

- Memoriale and Correopondence of C. J. Fox (London, 1863), ii. 122 On 8 April For wrote to the king that, since any cotion on Pitt's bill would make necectary an immediate decision on the matter, he had resolved to postpone suoh action until further progress had been made in the negotiations with the American commiseionern.

- On 9 April Fox carried withont division a motion further to postpone the conrideration of Pitt's bill.

- 23 Geo. III, o. 39.

24 For to Hartley, 10 April 1783 : Pabl. Reo. Off., Foreign Offoe, Amariog, cer. 1 B.

"Fox to Hartley, 10 June 1783: ibid. At this time tho one question at iasuo was the participation of American vesuels in the carrying trade between the islande and Great Britain.

"Privy Council Register, Geo. III, rxi, fo. 316. 
export to the United States rum, sugar, molasses, coffee, nuts, ginger, and pimonto. But the importation of American meat, dairy produce, and fish was forbidden, and the trade was confined entirely to British ships.

That this apparent alteration in the views of the ministry represents no change of opinion on the part of Fox is evident from his dispatches to Hartley of a later date, ${ }^{37}$ but it is certain that the cabinet was divided and that the order represents a victory for the more conservative section which attached itself to North. ${ }^{38}$ Not only is this supposition on the face of it reasonable, but there is evidence that the order was drafted, on the instructions of North himself, by William Knox, who had been for twelve years under-secretary for the colonies in the North administration. ${ }^{39}$ Knox, in fact, claims the credit of having suggested it and secured its adoption by the privy council in face of the opposition of Fox and Burke.; ${ }^{40}$ and, while his statements are unsupported save by general expressions of congratulation on the part of his friends, ${ }^{41}$ there is no reason for considering them untrue. Finally, we know that Eden was an active member of the committee of the privy council, in the hands of which affairs of trade had temporarily been placed, ${ }^{42}$ that he warmly approved of the order, and that he was in close touch with Knox. ${ }^{43}$ Other influences were also at work. The anxiety of the ministry as to the attitude of the Americans had just been relieved by the news that their ports were open to British vessels ${ }^{44}$ and by the arrival

n 'I still adhere in every particular to the system apon whioh my first instructions to you were planned': For to Hartley, 29 July 1783, Foreign Office, America, ger. $1 \mathrm{~B}$.

as Adame received from England exaggerated reports to this effect. "My advices from England are that Lord Sheffield with his friends . . are making a party unfriendly to us; that the ministry adopt their sentiments and measurea ; that For has lost his popularity and devoted himself to North, who has the King's ear and disposes of places . . . : Adams to Livingston, the Hague, 2 Aagust 1783, Works, viii. 130.

- Letter of Colonel Augustua North to Knox, dated by Knox, May 1783 : Knox Pepers, Hiff. MSS. Comm., Var. Call. vi. 191. Colonel North, on Lord North's behslf, requeste Knox to prepare the draft of an ant " "for regulating the commerce between our remaining British colonies, our West India Islands, and the United States, as well as any other acts it may be necessary to pass this Session" with regard to the intercourse between Fngland and America'. Subjoined is a memorandum by Knox stating that, on account of the ensbling act, legislation was unnecessary, and that he had therefore drafted orders in connoil instead: ibid. Sheffield, writing to Knox, 3 July 1783, expressed pleaswro that the order had been passed exactly as Knox drew it.

Knox to Lord Walsingham, 20 Angust 1787 : ibid. 188.

4. Sheffield to Knor, 3 July 1783; Visoonnt Sackville to Knor, 4 July 1783 and 20 August 1783: wid. 191, 192. Sackville expressed satisfaction that North had adopted Knox's plan, and declared that the cabinet would not have known how to proceed without him.

4 Roport of a meeting of the Committee on Plantations, 15 May 1783: Privy Council, Unbound Papers.

- Eden to Knox, 11 February 1782 : Knox Papers, ubi supra, p. 240.

“ Hartley to Fox, 20 June 1783: Foreign Offioe, America, sar. 1 в. 
of American ships in the United Kingdom. Lord Sheffield had just published his cleverly conceived and ably written Observations on the Commerce of the American States, for the express purpose of combating the principles underlying Pitt's bill. The popalarity of the book was so great, and its effect so marked, ${ }^{45}$ that it called forth from the American commissioners bitter complaints, ${ }^{46}$ and from Edward Gibbon a warm eulogy of its author as 'the defender if not the saviour of the navigation acts' .47 Whether or not John Adams was right in believing that the decision of the ministry was also swayed by the influence of jealous European powers is not clear. ${ }^{48}$

The July order in council, as I have said, embodies the policy pursued during the ten years following. Yet it was not regarded at the time as more than a temporary expedient, ${ }^{49}$ and the most important part of its history consists in the fact that it was maintained and in the end permanently adopted. Measures were soon set on foot for inducing the government to grant more liberal terms. From America came threats of retaliation, ${ }^{\text {so }}$ threats which were to some extent put into force by Maryland ${ }^{51}$ and Virginia ${ }^{52}$ before the close of the year. From the West Indies, where prices had risen from 50 to 100 per cent. on the publication of the order, ${ }^{63}$ and where there was a serious appre-

" Sheftield was congratulated on every side and was given the freedom of the city of Glasgow : Auckland Corr. i. 56 ; European Magazine for September, Novembar, and Deoomber 1783 ; Scot's Magazine for December 1783 ; Knox Papars, Hist. HSS. Comm., Var. Coll. vi. 191 ; Hist. MSS. Comm., MSS. in Royal Iratitution, iv. 207.

"Hartley to For, 17 and 24 July 1783: Foreign Office, America, ser. 1 B.

17 'The navigation ant, the palladium of Great Britain, was defended and perhaps saved by his pen': Memoirs (London, 1827), ii. 242.

48 Adams, Works (Boston, 1853), viii. 74, 85, 00, 98. Adams feared that England, France, and the other powers possessing oolonies in the West Indies would agree to exclude American vessels from any participation in the carrying trade of the islands. "The French . . . will say everything they can think of to persuade the English to deprive us of the trade of their West India Islands. They have already, with their emiseries, been the chief cause of the change of sentiments in London, on this head, against us.' But evidence is wanting to justify this conolusion. Certainly none exists in the Despatches from Paris, 1784-90, published by the Camden Society, 3rd series, rvi, Ivii.

"Fox to Hartley, 29 July 1783 : Foreign Office, America, ser. 1 B; Morning Chronicle, 19 Maroh 1784, reporting a speech of Eden in the house of commons, $18 \mathrm{Maroh}$.

4 Cf. Pennoylvania Packet, 4 August and 12 December 1783.

i Laros of Maryland (Annepolis, 1787), session of 3 November to 26 December 1783, c. 29. This act imposed a charge of 5a. per ton on British vessels entering and clearing and an additional duty of 2 per cent. ad valorem on British goods imported in British ships.

is Henning, Slatutes of Virginia, xi. 313, 8th of the Commonwealth, o. 5. This sot conferred upon Congress power to forbid the importation of British West Indian produce in British bottoms.

4 Answer to the Heads of Inquiry contained in the letter of the Secretary of State, 11 November 1784 : Colonial Office, 137. 84. The answer is dated 1 Febraary 1785. 
hension of famine, came a series of protests and appeals. ${ }^{\text {b4 }}$ Even in England a vigorous press campaign was set up. The coslition stuck to its guns and through a new enabling act extended the operation of the order in council until April 1784. But the opposition was as keen as ever when in December 1783 Pitt, the former advocate of the frest of intercourse, assumed charge of the government.

From the outset Pitt showed that he was prepared to afford the opponents of the existing restrictions every consideration. Negotiations were entered upon with the merchants with a view to a compromise, and it was suggested that West Indian ports should be opened to American vessels of less than eighty tons, ${ }^{55}$ vessels, in other words, which could not easily cross the ocean nor serve as a nursery for the American fleet. ${ }^{58}$ When the merchants, probably through over-confidence, refused to accept any limitation of tonnage, the matter was referred to the newly constituted committee of trade for investigation and report..$^{57}$ The voluminous minutes of this investigation well reward detailed examination, ${ }^{58}$ but we may here confine ourselves to the methods which the commissioners pursued, the principles upon which they acted, and the results at which they arrived. Their method deserves high praise. Working patiently for almost three months, ${ }^{59}$ they sought, obtained, and sifted evidence from every promising source in a manner which leaves no doubt as to their thoroughness and their honest desire to discover the truth.

The conclusion at which they arrived ${ }^{\infty 0}$ was that the loyal colonies were already able to supply a large proportion of the lumber and provisions which the West Indies required and would in about three years be ready to furnish the whole. If they failed to consume all the rum for which the planters had to find an American market, the people of the United States, to whom it was indispensable, would be glad to purchase the rest. For the carrying trade British shipping, operating on the old three-cornered principle,

4 Resolutions of the Committeo of West India Merohants, 26 November 1783 : Oolonial Offioe, 137. 82 ; Joumals of the Howse of Commons, xxrix. 840.

4 Library of Congrees, Franklin MS8, 1287. Benjamin Vaughan, writing to Henry Laurens, 27 February 1784, gives from memary an acoount of these negotiations. Seo slso the minutes of the meeting of West Indian planters and merchants at whioh the proposals were disenssed, Colonial Office, 137. 83.

"The explanation is furnished in correspondenop relative to the intercourse of the United States with the British colonies : Colonial Office, 325-6.

" Board of Trade, Min of Comm. of Trade, 3, fo. 1. The committee was estab. lished on 5 March 1784, and on the same day a petition of the West Indian merchants and planters, which conetituted the besis of the inquiry, was referred to it.

a The mass of evidence presented before the committoe is invalusble for the light it throws on the West Indian trade before and daring the war of the Amerioan Revolution.

- 10 Maroh to 31 May.

- Board of Trade, Min. of Comm. of Trade, 3, fo. 276 ff. 
would undoubtedly suffice. Retaliatory measures on the part of the Americans were not to be feared, and could in any event be defeated by the ease with which goods might be smuggled into their country and by the opening of free ports which their merchants would be sure to frequent. Hence the islands could be cultivated at a 'sufficient' profit without the freedom of intercourse for which the planters asked, although such profit might be less than that obtained before the war. On the basis of these conclusions, all of which were more or less contradicted by the allegations of the West Indians, the committee proceeded to recommend the adoption, for the time being, of a set of regulations corresponding in all essentials with those already in force. It is interesting, too, to note that the recommendations were based not only on facts, but on certain clearly stated principles. The privilege of supplying the islands as far as lay in their power belonged to the United Kingdom and the loyal colonies, because they were 'by every right exclusively entitled to the advantages to be derived from the trade', while the carrying trade was to be in British hands, because thus British naval strength might be increased and the sailors left idle by the close of the war might be prevented from entering the navy of the United States. A fuller vindication of the policy of the coalition or a clearer statement of some of the old commercial principles could scarcely have been offered.

Well grounded as the existing regulations were thus declared to be, they secured no permanent adoption for the space of more than four years. Enabling acts and orders in council, which differed in no essential respect from those of 1783 , were issued in unbroken succession until $1788 .^{\text {. }}$ The ministry, as it admitted, was merely testing the system, ${ }^{62}$ and to numerous protests and appeals returned steadily the answer that no reason for altering it had been shown. ${ }^{\circledR 3}$ Whether or not the ministers were justified in adhering to their position we must now inquire.

The conclusions reached by the committee in 1784 with regard to the possibilities of supply from British North America were

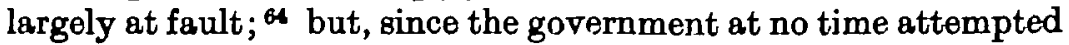

11 The last but one of the ensbling acts, 27 Geo. III, o. 7, provided for more rigid enforcement. The illegal introduction of Amerioan produce was mede punishable by the forfeiture of both vessel and cargo. No change, seve in phrasing, is to be observed in the successive orders in council: Privy Connoil Register, George III, xxi. 614, xxii. $91,186,351$, xxii. 121 , xxiv. 93 , xIv. 126.

- Grenville in the house of oommons, 11 February 1788: Moming Chronicte, 12 February 1788.

a e. g. Privy Conncil Register, George III, xxiv. 56, and Publ. Roc. Off., Baard of Trade, Min. of Comm. of Trade, 7, fo. 178.

at Evidence of Ainslee before the Committee of Trade, March 1789: Board of Trede, Min. of Comm. of Trade, 11, fo. 220, 246; statistics on the trade of the West Indies prepared by Irving, Inspector-General of Imports and Exports for Great 
to forbid the importation of raw produce from the United States, this fact is interesting rather than significant. In other respects the committee made fow mistakes. The carrying trade was immediately and completely taken over by British shipping. ${ }^{65}$ According to the most trustworthy statistics the supply of food appears to have been quite sufficient; ${ }^{B \theta}$ and, while periods of scarcity and distress occurred, they would seem to have been attributable rather to the hurricanes of 1784, 1785, and 1786, than to the restrictions laid upon the American trade. ${ }^{67}$ American measures of retaliation, needless to say, broke down, although attempted or recommended to Congress by nearly all the states. ${ }^{68}$ It is true, indeed, that more lumber had to be obtained within the islands, that prices both of food and lumber were high, ${ }^{90}$ and that illicit trade with the United States reached large proportions. ${ }^{70}$ But such 'inconveniences' were not to be considered so long as the 'sufficient' profit promised in 1784 was obtained, and the shipping, exports, and revenue of the mother country were fostered. When we note that by 1788 the trade of the islands with the mother country had increased both in exports and imports by some twenty-five per cent. over what it had been

Britain, Colonial Office, 390. 6. Knox, writing to Cemden, $\theta$ June 1804, admitted that the islands conld not yet be supplied from British North America : Hist. MASS. Comm, Var. Coll., vi. 221.

is Correspondence relating to the intercourse of the United States with the British oolonies: Board of Trade, Min. of Comm. of Trade, 11, fo. 203, and Colonial Office, 325-6.

- For instance, Treas., 64. 72, contains lists aigned by Davison, the oollector at Jamaioa, showing that in 1784 that island received 41,000 barrels of bread and flour (as compared with an average of about 35,000 barrels before 1775) and 14,000 feet of wood (as compared with 15,000 feet before 1775). 75 per cent. of the bread and flour and 65 per cont. of the lumber were from the United States As Jamaica was one of the last islands visited by vessels from Amerioa, it was apt to be lese fully supplied than the others. More wood was cut on the ialand than before 1775 .

" A committee of the assembly of Jamaica reported that 15,000 alaves had perished in the island from starvation or insufficient nutrition during the years immediately following 1783 , and that the scarcity of food was the result both of the hurricanes and the exalusion of American veseels : Journ of the Assoc. of Jamaica, viii. 429-30. Edwards (Hist. of Jamaica, 1801, ii. 511), enlarging upon this report, censured the government for ita polioy. It must be noted that the committee, in framing its report, was attempting to explain the attacks then being directed against the elave trade, and that its assertions were not based on evidence.

" Massachusetts, Rhode Island, Connectiout, New Hampehire, New York, New Jersey, Maryland, Virginia, North Carolina, and South Carolina, all conferred upon Congress porer to retaliate in commercial matters against Great Britain (See the laws of these states in the oollection of the Pennoylyania Historioal Society at Philadelphis.) But when Congress, in accordance with a report prepared by Jefferson and Chase, anked in April 1784 for power to regulate the trade of all the states for fifteen years, only three states gave their unreserved consent: Journals of Congress, iv. 392, $601-2$.

- Grenville, speaking in the house of commons, 14 Maroh 1787, admitted that the prioe of provieions and lumber purchased in Amerioa ' had risen far beyond all former precedent': Morning Chronide, 15 March 1787.

to Answer to Heads of Inquiry in the letter of the Secretary of State, February 1785 : Colonial Office, 137. 84. 
before the war, ${ }^{71}$ and that nearly six hundred vessels were employed in its transport, ${ }^{72}$ we must conclude that the objects of the ministry had been successfully accomplished, and that no reason existed for deferring longer the enactment of a statute which should make the existing regulations permanent. In February 1788 Grenville, the vice-president of the committee of trade, introduced such a bill, which, after encountering but a flicker of the old opposition, was easily passed. ${ }^{33}$

With the placing of this bill upon the statute book, the events with which this paper deals came practically to an end. A system from which the West. Indians had anticipated and prophesied sheer ruin had not terminated the growth of their prosperity. Regulations which the three leading statesmen of the time had condemned had been investigated, tested, and made permanent, because in point of fact they gave the results which in those days were most desired. The contexture of the whole, to use Burke's phrase, was but little torn, and if there was depreciation in value of any of the parts, it was mainly in the part now belonging to the Thirteen States, powerless in their divisions to resist the imposition of this last navigation act. Hence, during the five years which followed, there was no change in the policy of the government or in its results, while the West Indians, engrossed in their efforts to prevent the suppression of the slave trade, relinquished their opposition. Yet the system established by North and his friends was to have no extended existence, and when, in January 1793, England expelled Chauvelin, the envoy of the French Republic, it was already near virtual abrogation. How the government during the years of the great war attempted to secure a formal observance of the act of 1788 by passing annual acts of indemnity for the West Indian governors who were forced to permit its violation, how attempts to arrive at more logical conditions were made in the negotiations with Jay and with Munro and Pinckney, and how finally in $18 J 6$ American ships were by statute admitted, under slight restrictions, to West Indian ports cannot here be told. But a review of these events, by demonstrating the ease with which the Americans were able to recapture the West Indian trade, would probably strengthen the conclusion that, from the eighteenth-century point of view, the. British government was both wise and successful in its commercial policy in the West Indies during the ten years of peace.

HerberT C. BeLL.

"Imports into Great Britain from the West Indies, 1788-9, averaged in value

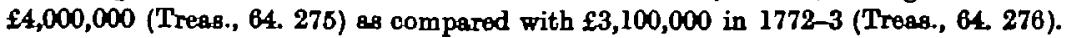
Exports to the West Indies, 1788-9, were valued at $£ 1,600,000$ (Colonial Office, 380. 5).

" Colonial Office, 390. 5, Miscellaneous Statiotiog on Trade.

"2 28 Goo. III, 0. 6: Journals of the Howse of Commons, xhii. 227, 278 